\title{
Update on the Role of Cannabinoid Receptors after Ischemic Stroke
}

\author{
Luciano S. A. Capettini, ${ }^{1,2}$ Silvia Q. Savergnini, ${ }^{1}$ Rafaela F. da Silva, ${ }^{1,3}$ Nikos Stergiopulos, ${ }^{1}$ \\ Robson A. S. Santos, ${ }^{3}$ François Mach, ${ }^{4}$ and Fabrizio Montecucco ${ }^{4}$ \\ ${ }^{1}$ Laboratory of Hemodynamics and Cardiovascular Technology, Institute of Bioengineering, Ecole Polytechnique Federale de Lausanne, \\ BM 5125, Station 17, 1015 Lausanne, Switzerland \\ ${ }^{2}$ Laboratory of Cardiovascular Pharmacology, Department of Pharmacology, Federal University of Minas Gerais, \\ 31270-901 Belo Horizonte, Brazil \\ ${ }^{3}$ Laboratory of Hypertension, Department of Physiology and Biophysics, Federal University of Minas Gerais, Belo Horizonte, \\ 31270-901, Brazil \\ ${ }^{4}$ Division of Cardiology, Foundation for Medical Researches, Department of Medical Specialties, University of Geneva, \\ Avenue de la Roseraie 64, 1211 Geneva, Switzerland
}

Correspondence should be addressed to Fabrizio Montecucco, fabrizio.montecucco@unige.ch

Received 25 November 2011; Revised 24 January 2012; Accepted 24 January 2012

Academic Editor: Giamila Fantuzzi

Copyright (C) 2012 Luciano S. A. Capettini et al. This is an open access article distributed under the Creative Commons Attribution License, which permits unrestricted use, distribution, and reproduction in any medium, provided the original work is properly cited.

\begin{abstract}
Cannabinoids are considered as key mediators in the pathophysiology of inflammatory diseases, including atherosclerosis. In particular, they have been shown to reduce the ischemic injury after acute cardiovascular events, such as acute myocardial infarction and ischemic stroke. These protective and anti-inflammatory properties on peripheral tissues and circulating inflammatory have been demonstrated to involve their binding with both selective cannabinoid type $1\left(\mathrm{CB}_{1}\right)$ and type $2\left(\mathrm{CB}_{2}\right)$ transmembrane receptors. On the other hands, the recent discoveries of novel different classes of cannabinoids and receptors have increased the complexity of this system in atherosclerosis. Although only preliminary data have been reported on the activities of novel cannabinoid receptors, several studies have already investigated the role of $\mathrm{CB}_{1}$ and $\mathrm{CB}_{2}$ receptors in ischemic stroke. While $\mathrm{CB}_{1}$ receptor activation has been shown to directly reduce atherosclerotic plaque inflammation, controversial data have been shown on neurotransmission and neuroprotection after stroke. Given its potent anti-inflammatory activities on circulating leukocytes, the $\mathrm{CB}_{2}$ activation has been proven to produce protective effects against acute poststroke inflammation. In this paper, we will update evidence on different cannabinoid-triggered avenues to reduce inflammation and neuronal injury in acute ischemic stroke.
\end{abstract}

\section{Introduction}

Ischemic stroke has become one of the leading causes of mortality and severe disability in several countries, including developing nations $[1,2]$. It is provoked by an acute, complete, and prolonged interruption of the arterial flow in the brain characterized by residual tissue infarction [3]. Although extensive studies have been performed to investigate the role of different factors influencing stroke sequelae, the disease pathophysiology remains largely unclear. Physical steps of the ischemic event (such as the transient or permanent interruption of the blood flow and the focal or global cerebral ischemia) are clearly pivotal determinants for the disease prognosis. However, these aspects do not explain some spatial heterogeneity in the cellular damage that might directly reflect neuronal intrinsic susceptibility to injury $[4,5]$. Since cannabinoids might accumulate in the ischemic brain $[6,7]$ and bind their receptors in neurons [8], promising neuroprotective strategies targeting this system to reduce the neuronal ischemic injury have been investigated. On the other hand, since cannabinoids have been shown to modulate brain resident microglial cells $[9,10]$, cerebral blood vessels [11-14], and circulating inflammatory cells $[15,16]$, a second therapeutic approach targeting 
postischemic inflammation has been also explored. In the following paragraphs, we will update scientific results on the role of the cannabinoid receptors as potential regulators of both nervous and immune systems after ischemic stroke $[9,17,18]$.

\section{Cannabinoids and Their Receptors}

Endogenous cannabinoids (endocannabinoids) are chemically amides and esters of long polyunsaturated fatty acids including arachidonoylethanolamide (anandamide [AEA]) and 2-arachidonoylglycerol (2-AG). AEA is a minor constituent of the $\mathrm{N}$-acylethanolamines (NAEs) family and has been found elevated in serum and plaques of patients with severe atherosclerotic diseases $[19,20]$. On the other, hand, 2-AG has been shown to reach higher concentrations than anandamide analogues (such as palmitoylethanolamide [PEA] and oleoylethanolamide [OEA]) in the brain and atherosclerotic vessels [21]. Synthetic cannabinoids have been also investigated in animal models showing an improvement of the ischemic injury in the liver, heart, and brain [22-24]. Furthermore, phytocannabinoids have been also isolated from the Cannabis sativa. Since this plant contains about 80 different cannabinoids, a strong work is still needed to test all these active compounds. This delay in cannabinoid research might be also due to the very low dose of certain cannabinoids in the plant. Thus, since $\Delta^{9}$-tetrahydrocannabidiol (THC) and cannabidiol (CBD) represent up to $40 \%$ of the total cannabinoid mass [25], these compounds have been considered as the most active mediators.

The effects of cannabinoids are classically attributed to the activation of the two major cannabinoids receptors (the cannabinoid receptors type $1\left[\mathrm{CB}_{1}\right]$ and type $2\left[\mathrm{CB}_{2}\right]$ ). These transmembrane receptors are pivotal components of the physiological endocannabinoid system together with endogenous cannabinoids (endocannabinoids), their transporters, and synthetic/degrading enzymes [26]. $\mathrm{CB}_{1}$ is highly expressed in the brain [27-31] as well as in cardiovascular tissues including the heart [32-34] and vascular vessels [35-38]. Although it has been recently shown in the brain $[39,40], \mathrm{CB}_{2}$ is mainly expressed in the immune and hematopoietic cells [10, 41-43]. Importantly, novel receptors capable of binding cannabinoids have been recently identified. In particular, the transient receptor potential vanilloid (TRPV) channels might be activated by cannabinoids [4446]. Among these channels, the activity and expression of TRPV type 1,3 , and 4 could be modulated by classical cannabinoids receptors agonists [41, 47-52]. On the other hand, there is growing evidence that cannabinoids can activate the peroxisome proliferator-activated receptors (PPAR, a family of nuclear receptors) in neurological diseases [53-57]. Although its activity has not been clarified yet, the orphan receptor GPR55 has been also identified to potentially bind cannabinoids and intracellularly transduce their signals [58, 59].

\section{Role of Cannabinoid Receptors in Poststroke Inflammatory Injury}

Some key events in the pathophysiology of ischemic stroke include increased levels of inflammatory cytokines in the brain, activation of microglia, and adhesion and migration of peripheral leukocytes as a result of damage to the blood-brain barrier [60]. A severe immunosuppression also characterized by spleen atrophy has been described to follow this initial inflammatory burst [61]. In order to inhibit the acute inflammatory phase (strongly associated with cerebral injury) [62], the treatment with $\Delta^{9}$-tetrahydrocannabinol (THC, a cannabinoid receptor agonist) has been shown to induce immunomodulatory properties in vitro [63-65]. Endocannabinoids (such as AEA and 2-AG) might be also released by immune cells and neurons, thus locally modulating immune response and cell differentiation within the brain $[66,67]$. Several immune cells (such as lymphocytes, monocytes, and neutrophils, capable of infiltrating the injured brain) have been shown to express on their surface membrane both $\mathrm{CB}_{1}$ and $\mathrm{CB}_{2}$ receptors [41, 47, 68-71]. $\mathrm{CB}_{1}$ receptor is particularly expressed on $\mathrm{T}$ lymphocytes and might be further upregulated by cannabinoid stimulation $[69,72-75]$. This mechanism might favor the paracrine protective activity of AEA, which is highly produced in the ischemic brain area and locally inhibits $\mathrm{T}$ lymphocyte proliferation [76]. Importantly, $\mathrm{CB}_{1}$ expression has been also confirmed on cerebral macrophage-like cells, suggesting a potential direct effects of cannabinoids also on populations resident in the brain [77]. On the other hand, the majority of beneficial effects of cannabinoids is associated with $\mathrm{CB}_{2}$ receptor activation, which is classically described to inhibit immune proinflammatory functions. $\mathrm{CB}_{2}$ receptor is also expressed in immune organs (such as thymus and spleen) [78] and circulating inflammatory cells (including T-, Blymphocytes, NK cells and monocytes and neutrophils) [7981]. Importantly, $\mathrm{CB}_{2}$ protein has been recently detected in astrocytes [82], microglia [83], neural subpopulations, and oligodendroglial progenitors [84], suggesting a potential direct regulation of $\mathrm{CB}_{2}$ in cerebral poststroke inflammation also in brain inflammatory cells [85]. The levels of $\mathrm{CB}_{2}$ receptor on microglial cells might depend on the cell activation state in response to infection, inflammation and stress $[66,86] . \mathrm{CB}_{2}$ receptor is also upregulated in restricted areas of the spinal cord in response to peripheral nerve injury [87], suggesting that neurons and resident inflammatory cells might benefit of cannabinoid treatments. Since $\mathrm{CB}_{1}$ and $\mathrm{CB}_{2}$ surface expression is upregulated during the inflammatory activation [66, 88-90], treatment with cannabinoids might be even more effective in the early post-ischemic phase. Treatment with the selective $\mathrm{CB}_{2}$ agonist JWH-133 was shown to significantly reduce microglial activation and inflammatory gene expression (such as interleukin [IL]6 , tumor necrosis factor [TNF]- $\alpha$, regulated on activation, normal T-cell expressed and secreted [RANTES], monocyte chemoattractant protein $[\mathrm{MCP}]-1$, and macrophage inflammatory peptide $[\mathrm{MIP}]-1 \alpha$ ) in a mouse model of permanent middle cerebral artery occlusion and focal cerebral ischemia [91]. Importantly, this potent anti-inflammatory activity 
was accompanied by the JWH-133-mediated improvement of brain infarction and neurological "clinical" outcomes [91]. Accordingly, pretreatment with $\mathrm{CB}_{2}$ agonists has been shown to attenuate the poststroke enhancement of leukocyte/endothelial cells interaction, adhesion molecule expression, and disruption of blood-brain barrier (BBB) [92-94]. In addition, $\mathrm{CB}_{2}$ knockout mice developed an increased cerebral infarction, accompanied by worsened neurological functions when compared to wild-type mice [92].

Confirming recent studies in other macrophage-mediated inflammatory diseases (such as atherosclerosis and rheumatoid arthritis) $[15,18,95]$, these studies clearly show that $\mathrm{CB}_{2}$ activation might actively reduce the post-stroke cerebral microglial inflammation.

Cannabinoids might also affect $\mathrm{T}$ lymphocyte function and survival [65]. Although the role of $\mathrm{T}$ lymphocytes in post-stroke inflammation has not been clarified yet in human beings [96, 97], recent evidence from mouse models indicated that these cells might modulate their functional capacities after an acute cerebral ischemia $[61,62,98,99]$. In particular, the $\mathrm{CD} 4+\mathrm{CD} 25+$ regulatory $\mathrm{T}$ cells have been suggested to play cerebroprotective activities in mice after a focal cerebral ischemia $[62,98]$. Therefore, the cannabinoidmediated benefits might involve the T lymphocyte response. In other inflammatory diseases, cannabinoid agonism has been shown to affect proliferation, polarization $[66,100]$, and cytolytic capacity [101] of T cells. Recently, Tanikawa and coworkers published that treatment with WIN-55,2122 favors the lymphocyte migration within the spleen, supporting that this cannabinoid agonist directly downregulates the immune response [102]. Accordingly, 2-AG strongly reduces mitogen-induced proliferation of mouse splenocytes [103]. These studies support a potential therapeutic role of cannabinoid agonists to reduce $\mathrm{T}$ lymphocyte-mediated inflammation in the post-stroke acute phase.

Although some effort has been made in the past decades to clarify the role of the cannabinoid system in poststroke inflammation, discrepancies deriving from the use of different types and doses of cannabinoids in both in vivo and in vitro models still exist and represent a major limitation to define clear conclusions.

\section{The Cannabinoid System in the Ischemic Neuronal Injury}

The acute reduction of blood flow with the consequent abrogation of oxygen and nutrient supply in the peripheral cerebral tissue has been shown to significantly modify the neural electrolytic equilibrium and metabolism. The cytosolic increase of reactive oxygen species (ROS), calcium, and sodium has been described to directly increase neuron necrosis and apoptosis in the early hours after the ischemic onset [104]. Normally, the burst of ROS in the cytosol is accompanied by a reduction in $\mathrm{pH}$, while the release of glutamate from the core of the infarcted area increases the permanency of high intracellular calcium concentrations, thus contributing to neuron injury. Deprivation of oxygen and glucose during ischemia also contributes to the increase in cytosolic $\mathrm{Ca}^{2+}$ via NMDA receptor-mediated pathways [105]. Since drugs blocking $\mathrm{Ca}^{2+}$ channels have been shown to protect cells, $\mathrm{Ca}^{2+}$ influx is considered as pivotal pathophysiological mechanism during an ischemic insult [106]. Together with the acute leukocyte influx, these neuronal modifications are probably the most relevant events in the pathophysiology of cerebral ischemia/reperfusion [107, 108].

Thus, cannabinoid-related mechanisms might serve as promising candidates for the reduction of neuronal ischemic injury. In particular, AEA and 2-AG have been shown to especially accumulate in the brain ischemic areas [13, 109]. This enhancement occurs exponentially in a timedependent manner [110], suggesting a potential protective role for endocannabinoids against the neuronal ischemic injury. However, several discrepancies on the activation of different cannabinoid receptors in experimental models of cerebral ischemia have to be clarified. In particular, the activation of $\mathrm{CB}_{1}$ receptor has been firstly indicated as a neuroprotective strategy in transient cerebral ischemia models [111]. On the other hand, Pegorini and coworkers also showed that treatment with rimonabant (a selective $\mathrm{CB}_{1}$ antagonist but also a VR1 vanilloid receptor agonist) might increase neuroprotection via the activation of this ligandgated cation channel [112]. These apparently paradoxical results may find an explanation in the different affinities of cannabinoids for their receptors. In fact, depending on the concentrations, cannabinoids might act as both agonists and antagonists for certain receptors in the same time. Importantly, an increase in $\mathrm{CB}_{2}$ receptor and TRPV1 and a concomitant decrease in $\mathrm{CB}_{1}$ cerebral expression were observed in mice underwent permanent middle cerebral artery occlusion and intraperitoneally injected with leptin [113]. The improvements of residual neurological disability were associated with reduced infarct volume in brain, suggesting that these receptors might beneficially influence the neuronal ischemic injury [113].

Taking into account these premises, the cannabinoid receptors have been shown to activate defined intracellular pathways in ischemic neurons $[111,114]$. Specifically, $\mathrm{CB}_{1}$ receptor activation triggers several protective signals involving phosphorylation of mitogen-activated protein kinase (MAPK) kinase 1/2 (MEK1/2), extracellular signalregulated kinase (ERK1/2), and nuclear factor-kappa B (NF$\kappa \mathrm{B})[114,115]$. These intracellular pathways might increase neuronal survival. The first-in-man study, investigating the cannabinoid therapeutic approach on neuroprotection, showed that the intravenous infusion of THC ameliorates the global and regional cerebral blood flow up to $2 \mathrm{~h}$ after the infusion of both low $(0.15 \mathrm{mg} / \mathrm{min})$ and high $(0.25 \mathrm{mg} / \mathrm{min})$ doses [116]. The encouraging therapeutic results of this study are in partial contrast with previous case reports, suggesting a potential relationship between stroke and chronic cannabis abuse in young human beings [117-120]. Importantly, Mateo and coworkers recently confirmed the potential association between cannabis and ischemic stroke recurrence in a young patient, without identifying the underlying pathophysiological mechanisms [121]. Evidence from autopsy examinations and imaging 
reports in both human beings and animal models has suggested that cannabis use might provoke cerebral stroke by favouring the development of atrial fibrillation, orthostatic hypotension, and cerebral artery vasospasm [122-124]. In a prospective study enrolling 48 young adults affected by ischemic stroke, Wolff and co-workers also showed that multifocal intracranial arterial stenosis was associated with cannabis consumption in 21\% [125]. Therefore, these preliminary results in human beings suggest using caution in the translational therapeutic approach of cannabinoid from animal models. Further clinical studies (possibly using more selective cannabinoid receptor agonist/antagonist) are needed to clarify the potential therapeutic role of these compounds against the ischemic stroke.

\section{Conclusion}

The endocannabinoid system is considered as a major modulator of the cerebral blood flow, neuroinflammation, and neuronal survival. Despite of some controversies, the activation of $\mathrm{CB}_{2}$ receptor has been shown to reduce cerebral injury associated with acute post-stroke inflammation and leukocyte infiltration. On the other hand, the direct role of $\mathrm{CB}_{1}$ in neuronal protection has not been clarified yet. Evidence from animal models and in vitro studies suggests a global protective role for cannabinoid receptors agonists in ischemic stroke. However, further studies are needed to clarify the role of the recently discovered cannabinoid receptors (such as GPR55 or VR1 vanilloid receptor) in the physiopathology of the infarcted brain and related inflammation. At this regard, both synthetic cannabinoids and endocannabinoids represent extremely promising therapeutic compounds. Since human studies are still missing, we cannot predict the potential clinical benefits of treatments targeting cannabinoid receptors in ischemic stroke. We believe that the "cannabinoid" approach represents an interesting therapeutic strategy still requiring further validations to improve neurologic and inflammatory outcomes in ischemic stroke.

\section{Conflict of Interests}

The authors declare that they have no conflict of interests.

\section{Acknowledgments}

This research was funded by the Brazilian Swiss Joint Research Program (BSJRP) to Dr. F. Mach, Dr. N. Stergiopulos, and A. S. Robson. This research was funded by EU FP7, Grant number 201668, AtheroRemo to Dr. F. Mach. This work was also supported by the Swiss National Science Foundation Grants to Dr. F. Mach (\#310030-118245) and Dr. Montecucco (\#32003B-134963/1).

\section{References}

[1] R. A. Egan and V. Biousse, "Update on ischemic stroke," Current Opinion in Ophthalmology, vol. 11, no. 6, pp. 395402, 2000.
[2] S. Stankovic and N. Majkic-Singh, "Genetic aspects of ischemic stroke: coagulation, homocysteine, and lipoprotein metabolism as potential risk factors," Critical Reviews in Clinical Laboratory Sciences, vol. 47, no. 2, pp. 72-123, 2010.

[3] J. D. Easton, J. L. Saver, G. W. Albers et al., "American Heart Association; American Stroke Association Stroke Council; Council on Cardiovascular Surgery and Anesthesia; Council on Cardiovascular Radiology and Intervention; Council on Cardiovascular Nursing; Interdisciplinary Council on Peripheral Vascular Disease. Definition and evaluation of transient ischemic attack: a scientific statement for healthcare professionals from the American Heart Association/American Stroke Association Stroke Council; Council on Cardiovascular Surgery and Anesthesia; Council on Cardiovascular Radiology and Intervention; Council on Cardiovascular Nursing; and the Interdisciplinary Council on Peripheral Vascular Disease. The American Academy of Neurology affirms the value of this statement as an educational tool for neurologists," Stroke, vol. 40, pp. 22762293, 2009.

[4] P. Lipton, "Ischemic cell death in brain neurons," Physiological Reviews, vol. 79, no. 4, pp. 1431-1568, 1999.

[5] L. K. Vaughn, G. Denning, K. L. Stuhr, H. De Wit, M. N. Hill, and C. J. Hillard, "Endocannabinoid signalling: has it got rhythm?” British Journal of Pharmacology, vol. 160, no. 3, pp. 530-543, 2010.

[6] C. J. Hillard and A. Jarrahian, "Accumulation of anandamide: evidence for cellular diversity," Neuropharmacology, vol. 48, no. 8, pp. 1072-1078, 2005.

[7] G. Pryce, Z. Ahmed, D. J. R. Hankey et al., "Cannabinoids inhibit neurodegeneration in models of multiple sclerosis," Brain, vol. 126, no. 10, pp. 2191-2202, 2003.

[8] M. Shen, T. M. Piser, V. S. Seybold, and S. A. Thayer, "Cannabinoid receptor agonists inhibit glutamatergic synaptic transmission in rat hippocampal cultures," Journal of Neuroscience, vol. 16, no. 14, pp. 4322-4334, 1996.

[9] E. J. Carrier, S. Patel, and C. J. Hillard, "Endocannabinoids in neuroimmunology and stress," Current Drug Targets, vol. 4, no. 6, pp. 657-665, 2005.

[10] K. Maresz, E. J. Carrier, E. D. Ponomarev, C. J. Hillard, and B. N. Dittel, "Modulation of the cannabinoid $\mathrm{CB}_{2}$ receptor in microglial cells in response to inflammatory stimuli," Journal of Neurochemistry, vol. 95, no. 2, pp. 437-445, 2005.

[11] Y. Chen, R. M. McCarron, Y. Ohara et al., "Human brain capillary endotheliumml: 2-Arachidonoglycerol (endocannabinoid) interacts with endothelin-1," Circulation Research, vol. 87, no. 4, pp. 323-327, 2000.

[12] D. Gebremedhin, A. R. Lange, W. B. Campbell, C. J. Hillard, and D. R. Harder, "Cannabinoid $\mathrm{CB}_{1}$ receptor of cat cerebral arterial muscle functions to inhibit L-type $\mathrm{Ca} 2+$ channel current," American Journal of Physiology, vol. 276, no. 6, pp. H2085-H2093, 1999.

[13] C. J. Hillard, W. S. V. Ho, J. Thompson et al., "Inhibition of 2arachidonoylglycerol catabolism modulates vasoconstriction of rat middle cerebral artery by the thromboxane mimetic, U-46619," British Journal of Pharmacology, vol. 152, no. 5, pp. 691-698, 2007.

[14] J. A. Wagner, Z. Járai, S. Bátkai, and G. Kunos, "Hemodynamic effects of cannabinoids: coronary and cerebral vasodilation mediated by cannabinoid $\mathrm{CB}_{1}$ receptors," European Journal of Pharmacology, vol. 423, no. 2-3, pp. 203-210, 2001.

[15] F. Montecucco, F. Burger, F. Mach, and S. Steffens, " $\mathrm{CB}_{2}$ cannabinoid receptor agonist JWH-015 modulates human monocyte migration through defined intracellular signaling 
pathways," American Journal of Physiology, vol. 294, no. 3, pp. H1145-H1155, 2008.

[16] F. Montecucco, S. Lenglet, V. Braunersreuther et al., " $\mathrm{CB}_{2}$ cannabinoid receptor activation is cardioprotective in a mouse model of ischemia/reperfusion," Journal of Molecular and Cellular Cardiology, vol. 46, no. 5, pp. 612-620, 2009.

[17] J. C. Ashton, "Cannabinoids for the treatment of inflammation," Current Opinion in Investigational Drugs, vol. 8, no. 5, pp. 373-384, 2007.

[18] S. Steffens, N. R. Veillard, C. Arnaud et al., "Low dose oral cannabinoid therapy reduces progression of atherosclerosis in mice," Nature, vol. 434, pp. 782-786, 2005.

[19] A. Quercioli, Z. Pataky, G. Vincenti et al., "Elevated endocannabinoid plasma levels are associated with coronary circulatory dysfunction in obesity," European Heart Journal, vol. 32, no. 11, pp. 1369-1378, 2011.

[20] F. Montecucco, V. Di Marzo, R. F. da Silva et al., "The activation of the cannabinoid receptor type $2\left(\mathrm{CB}_{2}\right)$ reduces neutrophilic protease-mediated vulnerability in atherosclerotic plaques," European Heart Journal, vol. 33, no. 7, pp. 846856, 2012.

[21] C. J. Hillard, "Role of cannabinoids and endocannabinoids in cerebral Ischemia," Current Pharmaceutical Design, vol. 14, no. 23, pp. 2347-2361, 2008.

[22] L. De Petrocellis, V. Vellani, A. Schiano-Moriello et al., "Plant-derived cannabinoids modulate the activity of transient receptor potential channels of ankyrin type-1 and melastatin type-8," Journal of Pharmacology and Experimental Therapeutics, vol. 325, no. 3, pp. 1007-1015, 2008.

[23] E. J. Downer and V. A. Campbell, "Phytocannabinoids, CNS cells and development: a dead issue?" Drug and Alcohol Review, vol. 29, no. 1, pp. 91-98, 2010.

[24] P. Pacher and G. Haskó, "Endocannabinoids and cannabinoid receptors in ischaemia-reperfusion injury and preconditioning," British Journal of Pharmacology, vol. 153, no. 2, pp. 252-262, 2008.

[25] J. Gertsch, R. G. Pertwee, and V. Di Marzo, "Phytocannabinoids beyond the Cannabis plant-do they exist?" British Journal of Pharmacology, vol. 160, no. 3, pp. 523-529, 2010.

[26] R. Vettor and C. Pagano, "The role of the endocannabinoid system in lipogenesis and fatty acid metabolism," Best Practice and Research, vol. 23, no. 1, pp. 51-63, 2009.

[27] T. Aguado, E. Romero, K. Monory et al., "The $\mathrm{CB}_{1}$ cannabinoid receptor mediates excitotoxicity-induced neural progenitor proliferation and neurogenesis," Journal of Biological Chemistry, vol. 282, no. 33, pp. 23892-23898, 2007.

[28] J. C. Ashton, I. Appleton, C. L. Darlington, and P. F. Smith, "Immunohistochemical localization of cerebrovascular cannabinoid $\mathrm{CB}_{1}$ receptor protein," Journal of Cardiovascular Pharmacology, vol. 44, no. 5, pp. 517-519, 2004.

[29] C. Benito, W. K. Kim, I. Chavarría et al., "A glial endogenous cannabinoid system is upregulated in the brains of macaques with simian immunodeficiency virus-induced encephalitis," Journal of Neuroscience, vol. 25, no. 10, pp. 2530-2536, 2005.

[30] A. G. Hohmann and M. Herkenham, "Localization of central cannabinoid $\mathrm{CB}_{1}$ receptor messenger RNA in neuronal subpopulations of rat dorsal root ganglia: a double-label in situ hybridization study," Neuroscience, vol. 90, no. 3, pp. 923-931, 1999.

[31] T. H. Smith, L. J. Sim-Selley, and D. E. Selley, "Cannabinoid $\mathrm{CB}_{1}$ receptor-interacting proteins: novel targets for central nervous system drug discovery?" British Journal of Pharmacology, vol. 160, no. 3, pp. 454-466, 2010.
[32] S. Bátkai, P. Mukhopadhyay, J. Harvey-White, R. Kechrid, P. Pacher, and G. Kunos, "Endocannabinoids acting at $\mathrm{CB}_{1}$ receptors mediate the cardiac contractile dysfunction in vivo in cirrhotic rats," American Journal of Physiology, vol. 293, no. 3, pp. H1689-H1695, 2007.

[33] A. C. Howlett, L. C. Blume, and G. D. Dalton, " $\mathrm{CB}_{1}$ cannabinoid receptors and their associated proteins," Current Medicinal Chemistry, vol. 17, no. 14, pp. 1382-1393, 2010.

[34] P. Mukhopadhyay, M. Rajesh, S. Bátkai et al., " $\mathrm{CB}_{1}$ cannabinoid receptors promote oxidative stress and cell death in murine models of doxorubicin-induced cardiomyopathy and in human cardiomyocytes," Cardiovascular Research, vol. 85, no. 4, pp. 773-784, 2010.

[35] S. Bátkai, Z. Járai, J. A. Wagner et al., "Endocannabinoids acting at vascular $\mathrm{CB}_{1}$ receptors mediate the vasodilated state in advanced liver cirrhosis," Nature Medicine, vol. 7, no. 7, pp. 827-832, 2001.

[36] A. T. Chaytor, P. E. M. Martin, W. H. Evans, M. D. Randall, and T. M. Griffith, "The endothelial component of cannabinoid-induced relaxation in rabbit mesenteric artery depends on gap junctional communication," Journal of Physiology, vol. 520, no. 2, pp. 539-550, 1999.

[37] M. Rajesh, P. Mukhopadhyay, G. Haskó, L. Liaudet, K. MacKie, and P. Pacher, "Cannabinoid-1 receptor activation induces reactive oxygen species-dependent and -independent mitogen-activated protein kinase activation and cell death in human coronary artery endothelial cells," British Journal of Pharmacology, vol. 160, no. 3, pp. 688-700, 2010.

[38] V. Tiyerili, S. Zimmer, S. Jung et al., " $\mathrm{CB}_{1}$ receptor inhibition leads to decreased vascular AT1 receptor expression, inhibition of oxidative stress and improved endothelial function," Basic Research in Cardiology, vol. 105, no. 4, pp. 465-477, 2010.

[39] E. Núñez, C. Benito, M. R. Pazos et al., "Cannabinoid $\mathrm{CB}_{2}$ receptors are expressed by perivascular microglial cells in the human brain: an Immunohistochemical Study," Synapse, vol. 53, no. 4, pp. 208-213, 2004.

[40] J. Palazuelos, T. Aguado, A. Egia, R. Mechoulam, M. Guzmán, and I. Galve-Roperh, "Non-psychoactive $\mathrm{CB}_{2}$ cannabinoid agonists stimulate neural progenitor proliferation.", The FASEB Journal, vol. 20, no. 13, pp. 2405-2407, 2006.

[41] B. K. Atwood and K. MacKie, " $\mathrm{CB}_{2}$ : a cannabinoid receptor with an identity crisis," British Journal of Pharmacology, vol. 160, no. 3, pp. 467-479, 2010.

[42] K. R. Kasten, J. Tschöp, M. H. Tschöp, and C. C. Caldwell, "The cannabinoid 2 receptor as a potential therapeutic target for sepsis," Endocrine, Metabolic and Immune Disorders, vol. 10, no. 3, pp. 224-234, 2010.

[43] X. Ni, E. B. Geller, M. J. Eppihimer, T. K. Eisenstein, M. W. Adler, and R. F. Tuma, "Win 55212-2, a cannabinoid receptor agonist, attenuates leukocyte/endothelial interactions in an experimental autoimmune encephalomyelitis model," Multiple Sclerosis, vol. 10, no. 2, pp. 158-164, 2004.

[44] S. Akerman, H. Kaube, and P. J. Goadsby, "Anandamide acts as a vasodilator of dural blood vessels in vivo by activating TRPV1 receptors," British Journal of Pharmacology, vol. 142, no. 8, pp. 1354-1360, 2004.

[45] C. L. Baker and J. J. McDougall, "The cannabinomimetic arachidonyl-2-chloroethylamide (ACEA) acts on capsaicinsensitive TRPV1 receptors but not cannabinoid receptors in rat joints," British Journal of Pharmacology, vol. 142, no. 8, pp. 1361-1367, 2004.

[46] M. T. Dannert, A. Alsasua, E. Herradon, M. I. Martín, and V. López-Miranda, "Vasorelaxant effect of Win 55,212-2 in 
rat aorta: new mechanisms involved," Vascular Pharmacology, vol. 46, no. 1, pp. 16-23, 2007.

[47] A. C. Campos and F. S. Guimarães, "Evidence for a potential role for TRPV1 receptors in the dorsolateral periaqueductal gray in the attenuation of the anxiolytic effects of cannabinoids," Progress in Neuro-Psychopharmacology and Biological Psychiatry, vol. 33, no. 8, pp. 1517-1521, 2009.

[48] E. Herradón, M. I. Martín, and V. López-Miranda, "Characterization of the vasorelaxant mechanisms of the endocannabinoid anandamide in rat aorta," British Journal of Pharmacology, vol. 152, no. 5, pp. 699-708, 2007.

[49] L. Moezi, S. A. Gaskari, H. Liu, S. K. Baik, A. R. Dehpour, and S. S. Lee, "Anandamide mediates hyperdynamic circulation in cirrhotic rats via $\mathrm{CB}_{1}$ and VR1 receptors," British Journal of Pharmacology, vol. 149, no. 7, pp. 898-908, 2006.

[50] L. De Petrocellis and V. Di Marzo, "Non- $\mathrm{CB}_{1}$, Non$\mathrm{CB}_{2}$ receptors for endocannabinoids, plant cannabinoids, and synthetic cannabimimetics: focus on G-protein-coupled receptors and transient receptor potential channels," Journal of Neuroimmune Pharmacology, vol. 5, no. 1, pp. 103-121, 2010.

[51] L. de Petrocellis, P. Orlando, A. S. Moriello et al., "Cannabinoid actions at TRPV channels: effects on TRPV3 and TRPV4 and their potential relevance to gastrointestinal inflammation," Acta Physiologica, vol. 204, no. 2, pp. 255 266, 2012.

[52] V. Di Marzo and L. De Petrocellis, "Endocannabinoids as regulators of transient receptor potential (TRP) channels: a further opportunity to develop new endocannabinoid-based therapeutic drugs," Current Medicinal Chemistry, vol. 17, no. 14, pp. 1430-1449, 2010.

[53] S. Burstein, "PPAR- $\gamma$ : a nuclear receptor with affinity for cannabinoids," Life Sciences, vol. 77, no. 14, pp. 1674-1684, 2005.

[54] J. Fu, S. Gaetani, F. Oveisi et al., "Oleylethanolamide regulates feeding and body weight through activation of the nuclear receptor PPAR- $\alpha$," Nature, vol. 425, no. 6953, pp. 90-93, 2003.

[55] S. E. O'Sullivan and D. A. Kendall, "Cannabinoid activation of peroxisome proliferator-activated receptors: potential for modulation of inflammatory disease," Immunobiology, vol. 215, no. 8, pp. 611-616, 2010.

[56] S. E. O'Sullivan, E. J. Tarling, A. J. Bennett, D. A. Kendall, and M. D. Randall, "Novel time-dependent vascular actions of $\Delta 9$-tetrahydrocannabinol mediated by peroxisome proliferator-activated receptor gamma," Biochemical and Biophysical Research Communications, vol. 337, no. 3, pp. 824-831, 2005.

[57] C. E. Rockwell, N. T. Snider, J. T. Thompson, J. P. Vanden Heuvel, and N. E. Kaminski, "Interleukin-2 suppression by 2 -arachidonyl glycerol is mediated through peroxisome proliferator-activated receptor $\gamma$ independently of cannabinoid receptors 1 and 2," Molecular Pharmacology, vol. 70, no. 1, pp. 101-111, 2006.

[58] M. Brusberg, S. Arvidsson, D. Kang, H. Larsson, E. Lindström, and V. Martinez, " $\mathrm{CB}_{1}$ receptors mediate the analgesic effects of cannabinoids on colorectal distension-induced visceral pain in rodents," Journal of Neuroscience, vol. 29, no. 5, pp. 1554-1564, 2009.

[59] A. Irving, "New blood brothers: the GPR55 and $\mathrm{CB}_{2}$ partnership," Cell Research, vol. 21, no. 10, pp. 1391-1392, 2011.
[60] U. Dirnagl, C. Iadecola, and M. A. Moskowitz, "Pathobiology of ischaemic stroke: an integrated view," Trends in Neurosciences, vol. 22, no. 9, pp. 391-397, 1999.

[61] S. Dziennis, S. Mader, K. Akiyoshi et al., "Therapy with recombinant T-cell receptor ligand reduces infarct size and infiltrating inflammatory cells in brain after middle cerebral artery occlusion in mice," Metabolic Brain Disease, vol. 26, no. 2, pp. 123-133, 2011.

[62] X. Ren, K. Akiyoshi, A. A. Vandenbark, P. D. Hurn, and H. Offner, "CD4+FoxP3+ regulatory T-cells in cerebral ischemic stroke,” Metabolic Brain Disease, vol. 26, pp. 87-90, 2011.

[63] M. D. Srivastava, B. I. S. Srivastava, and B. Brouhard, " $\Delta 9$ Tetrahydrocannabinol and cannabidiol alter cytokine production by human immune cells," Immunopharmacology, vol. 40, no. 3, pp. 179-185, 1998.

[64] M. Yuan, S. M. Kiertscher, Q. Cheng, R. Zoumalan, D. P. Tashkin, and M. D. Roth, " $\Delta 9$-Tetrahydrocannabinol regulates Th1/Th2 cytokine balance in activated human $\mathrm{T}$ cells," Journal of Neuroimmunology, vol. 133, no. 1-2, pp. 124$131,2002$.

[65] L. X. Zhu, S. Sharma, M. Stolina et al., " $\Delta$-9-tetrahydrocannabinol inhibits antitumor immunity by a $\mathrm{CB}_{2}$ receptormediated, cytokine-dependent pathway," Journal of Immunology, vol. 165, no. 1, pp. 373-380, 2000.

[66] J. L. Croxford and T. Yamamura, "Cannabinoids and the immune systemml: potential for the treatment of inflammatory diseases?" Journal of Neuroimmunology, vol. 166, no. 1-2, pp. 3-18, 2005.

[67] P. Massi, A. Vaccani, and D. Parolaro, "Cannabinoids, immune system and cytokine network," Current Pharmaceutical Design, vol. 12, no. 24, pp. 3135-3146, 2006.

[68] Z. Mouslech and V. Valla, "Endocannabinoid systemml: an overview of its potential in current medical practice," Neuroendocrinology Letters, vol. 30, no. 2, pp. 153-179, 2009.

[69] B. Rossi, E. Zenaro, S. Angiari et al., "Inverse agonism of cannabinoid $\mathrm{CB}_{1}$ receptor blocks the adhesion of encephalitogenic $\mathrm{T}$ cells in inflamed brain venules by a protein kinase A-dependent mechanism," Journal of Neuroimmunology, vol. 233, pp. 97-105, 2011.

[70] G. B. Stefano, T. V. Bilfinger, C. M. Rialas, and D. G. Deutsch, "2-arachidonyl-glycerol stimulates nitric oxide release from human immune and vascular tissues and invertebrate immunocytes by cannabinoid receptor 1," Pharmacological Research, vol. 42, no. 4, pp. 317-322, 2000.

[71] S. Steffens and F. Mach, "Towards a therapeutic use of selective $\mathrm{CB}_{2}$ cannabinoid receptor ligands for atherosclerosis," Future Cardiology, vol. 2, no. 1, pp. 49-53, 2006.

[72] B. L. F. Kaplan, A. E. B. Springs, and N. E. Kaminski, "The profile of immune modulation by cannabidiol (CBD) involves deregulation of nuclear factor of activated $\mathrm{T}$ cells (NFAT)," Biochemical Pharmacology, vol. 76, no. 6, pp. 726737, 2008.

[73] S. J. Mnich, R. R. Hiebsch, R. M. Huff, and S. Muthian, "Anti-inflammatory properties of $\mathrm{CB}_{1}$-receptor antagonist involves $\beta 2$ adrenoceptors," Journal of Pharmacology and Experimental Therapeutics, vol. 333, no. 2, pp. 445-453, 2010.

[74] C. A. Newton, P. J. Chou, I. Perkins, and T. W. Klein, " $\mathrm{CB}_{1}$ and $\mathrm{CB}_{2}$ cannabinoid receptors mediate different aspects of delta-9-tetrahydrocannabinol (THC)-induced T helper cell shift following immune activation by legionella pneumophila infection," Journal of Neuroimmune Pharmacology, vol. 4, no. 1, pp. 92-102, 2009.

[75] C. Börner, V. Höllt, and J. Kraus, "Activation of human T cells induces upregulation of cannabinoid receptor type 1 
transcription," NeuroImmunoModulation, vol. 14, no. 6, pp. 281-286, 2007.

[76] H. Schwarz, F. J. Blanco, and M. Lotz, "Anadamide, an endogenous cannabinoid receptor agonist inhibits lymphocyte proliferation and induces apoptosis," Journal of Neuroimmunology, vol. 55, no. 1, pp. 107-115, 1994.

[77] D. Sinha, T. I. Bonner, N. R. Bhat, and L. A. Matsuda, "Expression of the $\mathrm{CB}_{1}$ cannabinoid receptor in macrophagelike cells from brain tissue: immunochemical characterization by fusion protein antibodies," Journal of Neuroimmunology, vol. 82, no. 1, pp. 13-21, 1998.

[78] A. R. Schatz, M. Lee, R. B. Condie, J. T. Pulaski, and N. E. Kaminski, "Cannabinoid receptors $\mathrm{CB}_{1}$ and $\mathrm{CB}_{2}$ : a characterization of expression and adenylate cyclase modulation within the immune system," Toxicology and Applied Pharmacology, vol. 142, no. 2, pp. 278-287, 1997.

[79] P. Carayon, J. Marchand, D. Dussossoy et al., "Modulation and functional involvement of $\mathrm{CB}_{2}$ peripheral cannabinoid receptors during B-cell differentiation," Blood, vol. 92, no. 10, pp. 3605-3615, 1998.

[80] S. Galiegue, S. Mary, J. Marchand et al., "Expression of central and peripheral cannabinoid receptors in human immune tissues and leukocyte subpopulations," European Journal of Biochemistry, vol. 232, no. 1, pp. 54-61, 1995.

[81] L. Mestre, F. Docagne, F. Correa et al., "A cannabinoid agonist interferes with the progression of a chronic model of multiple sclerosis by downregulating adhesion molecules," Molecular and Cellular Neuroscience, vol. 40, no. 2, pp. 258-266, 2009.

[82] N. Stella, "Cannabinoid and cannabinoid-like receptors in microglia, astrocytes, and astrocytomas," Glia, vol. 58, no. 9, pp. 1017-1030, 2010.

[83] E. Núñez, C. Benito, R. M. Tolón, C. J. Hillard, W. S. T. Griffin, and J. Romero, "Glial expression of cannabinoid $\mathrm{CB}_{2}$ receptors and fatty acid amide hydrolase are beta amyloidlinked events in Down's syndrome," Neuroscience, vol. 151, no. 1, pp. 104-110, 2008.

[84] E. S. Onaivi, "Neuropsychobiological evidence for the functional presence and expression of cannabinoid $\mathrm{CB}_{2}$ receptors in the brain," Neuropsychobiology, vol. 54, no. 4, pp. 231-246, 2007.

[85] J. C. Ashton and M. Glass, "The cannabinoid $\mathrm{CB}_{2}$ receptor as a target for inflammation-dependent neurodegeneration," Current Neuropharmacology, vol. 5, no. 2, pp. 73-80, 2007.

[86] S. J. Carlisle, F. Marciano-Cabral, A. Staab, C. Ludwick, and G. A. Cabral, "Differential expression of the $\mathrm{CB}_{2}$ cannabinoid receptor by rodent macrophages and macrophage-like cells in relation to cell activation," International Immunopharmacology, vol. 2, no. 1, pp. 69-82, 2002.

[87] J. Zhang, C. Hoffert, H. K. Vu, T. Groblewski, S. Ahmad, and D. O'Donnell, "Induction of $\mathrm{CB}_{2}$ receptor expression in the rat spinal cord of neuropathic but not inflammatory chronic pain models," European Journal of Neuroscience, vol. 17, no. 12, pp. 2750-2754, 2003.

[88] K. Maresz, G. Pryce, E. D. Ponomarev et al., "Direct suppression of CNS autoimmune inflammation via the cannabinoid receptor $\mathrm{CB}_{1}$ on neurons and $\mathrm{CB}_{2}$ on autoreactive T cells," Nature Medicine, vol. 13, no. 4, pp. 492-497, 2007.

[89] T. W. Klein, C. Newton, W. Zhu, Y. Daaka, and H. Friedman, " $\Delta$ 9-tetrahydrocannabinol, cytokines, and immunity to Legionella pneumophila," Proceedings of the Society for Experimental Biology and Medicine, vol. 209, no. 3, pp. 205213, 1995.

[90] Y. Daaka, H. Friedman, and T. W. Klein, "Cannabinoid receptor proteins are increased in Jurkat, human T-cell line after mitogen activation," Journal of Pharmacology and Experimental Therapeutics, vol. 276, no. 2, pp. 776-783, 1996.

[91] J. G. Zarruk, D. Fernández-López, I. García-Yébenes et al., "Cannabinoid type 2 receptor activation downregulates stroke-induced classic and alternative brain macrophage/microglial activation concomitant to neuroprotection," Stroke, vol. 43, no. 1, pp. 211-219, 2012.

[92] M. Zhang, M. W. Adler, M. E. Abood, D. Ganea, J. Jallo, and R. F. Tuma, " $\mathrm{CB}_{2}$ receptor activation attenuates microcirculatory dysfunction during cerebral ischemic/reperfusion injury," Microvascular Research, vol. 78, no. 1, pp. 86-94, 2009.

[93] M. Zhang, B. R. Martin, M. W. Adler, R. K. Razdan, J. I. Jallo, and R. F. Tuma, "Cannabinoid $\mathrm{CB}_{2}$ receptor activation decreases cerebral infarction in a mouse focal ischemia/reperfusion model," Journal of Cerebral Blood Flow and Metabolism, vol. 27, no. 7, pp. 1387-1396, 2007.

[94] Y. Zhao, Z. Yuan, Y. Liu et al., "Activation of cannabinoid $\mathrm{CB}_{2}$ receptor ameliorates atherosclerosis associated with suppression of adhesion molecules," Journal of Cardiovascular Pharmacology, vol. 55, no. 3, pp. 292-298, 2010.

[95] R. B. Zurier, R. G. Rossetti, J. H. Lane, J. M. Goldberg, S. A. Hunter, and S. H. Burstein, "Dimethylheptyl-THC-11 OIC acid: a nonpsychoactive antiinflammatory agent with a cannabinoid template structure," Arthritis and Rheumatism, vol. 41, no. 1, pp. 163-170, 1998.

[96] K. G. Haeusler, W. U. H. Schmidt, F. Foehring et al., "Immune responses after acute ischemic stroke or myocardial infarction," International Journal of Cardiology, vol. 155, no. 3, pp. 372-377, 2012.

[97] S. Hendrix and R. Nitsch, "The role of T helper cells in neuroprotection and regeneration," Journal of Neuroimmunology, vol. 184, no. 1-2, pp. 100-112, 2007.

[98] A. Hug, A. Liesz, B. Muerle et al., "Reduced efficacy of circulating costimulatory cells after focal cerebral ischemia," Stroke, vol. 42, no. 12, pp. 3580-3586, 2011.

[99] G. Yilmaz, T. V. Arumugam, K. Y. Stokes, and D. N. Granger, "Role of T lymphocytes and interferon- $\gamma$ in ischemic stroke," Circulation, vol. 113, no. 17, pp. 2105-2112, 2006.

[100] V. L. Hegde, S. Hegde, B. F. Cravatt, L. J. Hofseth, M. Nagarkatti, and P. S. Nagarkatti, "Attenuation of experimental autoimmune hepatitis by exogenous and endogenous cannabinoids: involvement of regulatory T cells," Molecular Pharmacology, vol. 74, no. 1, pp. 20-33, 2008.

[101] P. W. Wacnik, K. M. Luhr, R. H. Hill, H. G. Ljunggren, K. Kristensson, and M. Svensson, "Cannabinoids affect dendritic cell (DC) potassium channel function and modulate DC T cell stimulatory capacity," Journal of Immunology, vol. 181, no. 5, pp. 3057-3066, 2008.

[102] T. Tanikawa, K. Kurohane, and Y. Imai, "Regulatory effect of cannabinoid receptor agonist on chemokine-induced lymphocyte chemotaxis," Biological and Pharmaceutical Bulletin, vol. 34, no. 7, pp. 1090-1093, 2011.

[103] M. Lee, Kyu Hwan Yang, and N. E. Kaminski, "Effects of putative cannabinoid receptor ligands, anandamide and 2arachidonyl-glycerol, on immune function in $\mathrm{B} 6 \mathrm{C} 3 \mathrm{~F} 1$ mouse splenocytes," Journal of Pharmacology and Experimental Therapeutics, vol. 275, no. 2, pp. 529-536, 1995.

[104] F. Wiegand, W. Liao, C. Busch et al., "Respiratory chain inhibition induces tolerance to focal cerebral ischemia," Journal of Cerebral Blood Flow and Metabolism, vol. 19, no. 11, pp. 1229-1237, 1999.

[105] Y. Zhang and P. Lipton, "Cytosolic Ca2+ changes during in vitro ischemia in rat hippocampal slices: major roles for 
glutamate and $\mathrm{Na}+$ dependent $\mathrm{Ca} 2+$ release from mitochondria," Journal of Neuroscience, vol. 19, no. 9, pp. 3307-3315, 1999.

[106] Y. Chen, Y.-H. Tsai, and S.-H. Tseng, "The potential of tetrandrine as a protective agent for ischemic stroke," Molecules, vol. 16, no. 9, pp. 8020-8032, 2011.

[107] P. Agostinho, R. A. Cunha, and C. Oliveira, "Neuroinflammation, oxidative stress and the pathogenesis of Alzheimer's disease," Current Pharmaceutical Design, vol. 16, no. 25, pp. 2766-2778, 2010.

[108] P. F. Stahel, W. R. Smith, J. Bruchis, and C. H. Rabb, "Peroxisome proliferator-activated receptors: "Key" regulators of neuroinflammation after traumatic brain injury," PPAR Research, vol. 2008, Article ID 538141, 7 pages, 2008.

[109] J. Hwang, C. Adamson, D. Butler, D. R. Janero, A. Makriyannis, and B. A. Bahr, "Enhancement of endocannabinoid signaling by fatty acid amide hydrolase inhibition: a neuroprotective therapeutic modality," Life Sciences, vol. 86, no. 1516, pp. 615-623, 2010.

[110] S. E. O'Sullivan, D. A. Kendall, and M. D. Randall, "Timedependent vascular effects of endocannabinoids mediated by peroxisome proliferator-activated receptor gamma (PPAR $\gamma$ )," PPAR Research, vol. 2009, Article ID 425289, 9 pages, 2009.

[111] F. Mach, F. Montecucco, and S. Steffens, "Cannabinoid receptors in acute and chronic complications of atherosclerosis," British Journal of Pharmacology, vol. 153, no. 2, pp. 290-298, 2008.

[112] S. Pegorini, A. Zani, D. Braida, C. Guerini-Rocco, and M. Sala, "Vanilloid VR1 receptor is involved in rimonabantinduced neuroprotection," British Journal of Pharmacology, vol. 147, no. 5, pp. 552-559, 2006.

[113] Y. Avraham, N. Davidi, M. Porat et al., "Leptin reduces infarct size in association with enhanced expression of $\mathrm{CB}_{2}$, TRPV1, SIRT-1 and leptin receptor," Current Neurovascular Research, vol. 7, no. 2, pp. 136-143, 2010.

[114] D. Panikashvili, R. Mechoulam, S. M. Beni, A. Alexandrovich, and E. Shohami, " $\mathrm{CB}_{1}$ cannabinoid receptors are involved in neuroprotection via NF- $\kappa \mathrm{B}$ inhibition," Journal of Cerebral Blood Flow and Metabolism, vol. 25, no. 4, pp. 477-484, 2005.

[115] J. Du, Q. Wang, B. Hu et al., "Involvement of ERK 1/2 activation in electroacupuncture pretreatment via cannabinoid $\mathrm{CB}_{1}$ receptor in rats," Brain Research, vol. 1360, pp. 1-7, 2010.

[116] R. J. Mathew, W. H. Wilson, T. G. Turkington et al., "Time course of tetrahydrocannabinol-induced changes in regional cerebral blood flow measured with positron emission tomography," Psychiatry Research - Neuroimaging, vol. 116, no. 3, pp. 173-185, 2002.

[117] N. N. Singh, Y. Pan, S. Muengtaweeponsa, T. J. Geller, and S. Cruz-Flores, "Cannabis-related stroke: case series and review of literature," Journal of Stroke and Cerebrovascular Diseases. In press.

[118] B. Trojak, S. Leclerq, V. Meille et al., "Stroke with neuropsychiatric sequelae after cannabis use in a man: a case report," Journal of Medical Case Reports, vol. 5, article 264, 2011.

[119] J. Finsterer, P. Christian, and K. Wolfgang, "Occipital stroke shortly after cannabis consumption," Clinical Neurology and Neurosurgery, vol. 106, no. 4, pp. 305-308, 2004.

[120] T. M. Lawson, "Stroke and transient ischaemic attacks in association with substance abuse in a young man," Postgraduate Medical Journal, vol. 72, no. 853, pp. 692-693, 1996.

[121] I. Mateo, A. Pinedo, M. Gomez-Beldarrain, J. M. Basterretxea, and J. C. Garcia-Monco, "Recurrent stroke associated with cannabis use," Journal of Neurology, Neurosurgery and Psychiatry, vol. 76, no. 3, pp. 435-437, 2005.

[122] D. A. Kosior, K. J. Filipiak, P. Stolarz, and G. Opolski, "Paroxysmal atrial fibrillation following marijuana intoxication: a two-case report of possible association," International Journal of Cardiology, vol. 78, no. 2, pp. 183-184, 2001.

[123] K. Varga, K. D. Lake, D. Huangfu, P. G. Guyenet, and G. Kunos, "Mechanism of the hypotensive action of anandamide in anesthetized rats," Hypertension, vol. 28, no. 4, pp. 682-686, 1996.

[124] E. F. Ellis, S. F. Moore, and K. A. Willoughby, "Anandamide and $\triangle 9$-THC dilation of cerebral arterioles is blocked by indomethacin," American Journal of Physiology, vol. 269, pp. H1859-H1864, 1995.

[125] V. Wolff, V. Lauer, O. Rouyer et al., "Cannabis use, ischemic stroke, and multifocal intracranial vasoconstriction: a prospective study in 48 consecutive young patients," Stroke, vol. 42, no. 6, pp. 1778-1780, 2011. 


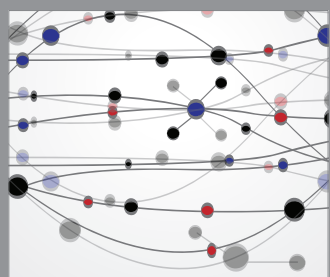

The Scientific World Journal
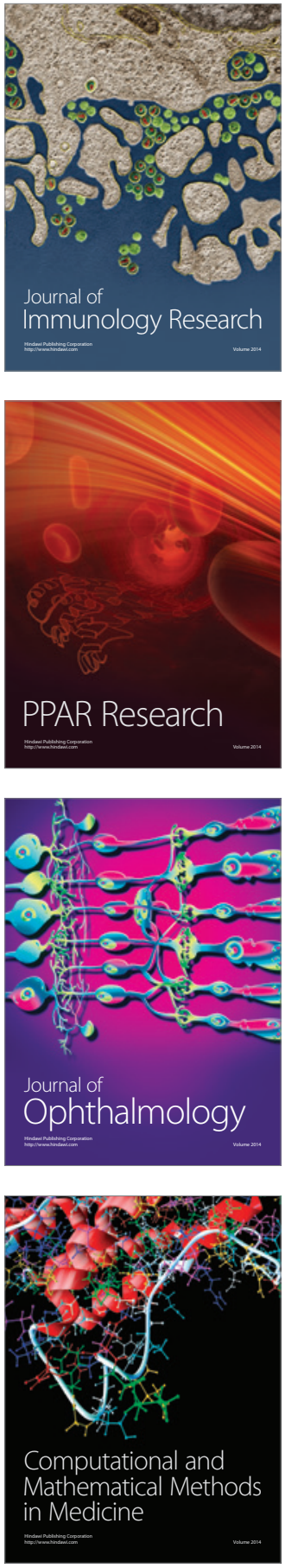

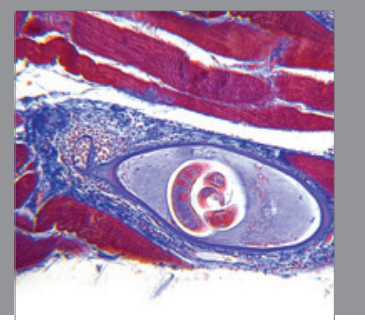

Gastroenterology

Research and Practice
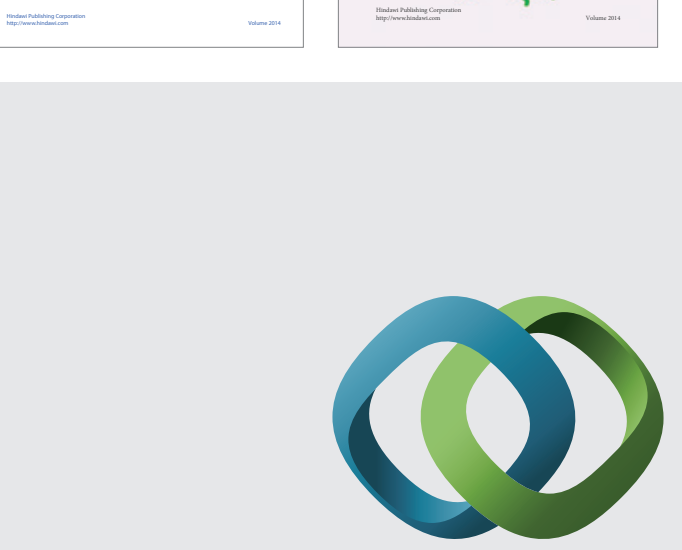

\section{Hindawi}

Submit your manuscripts at

http://www.hindawi.com
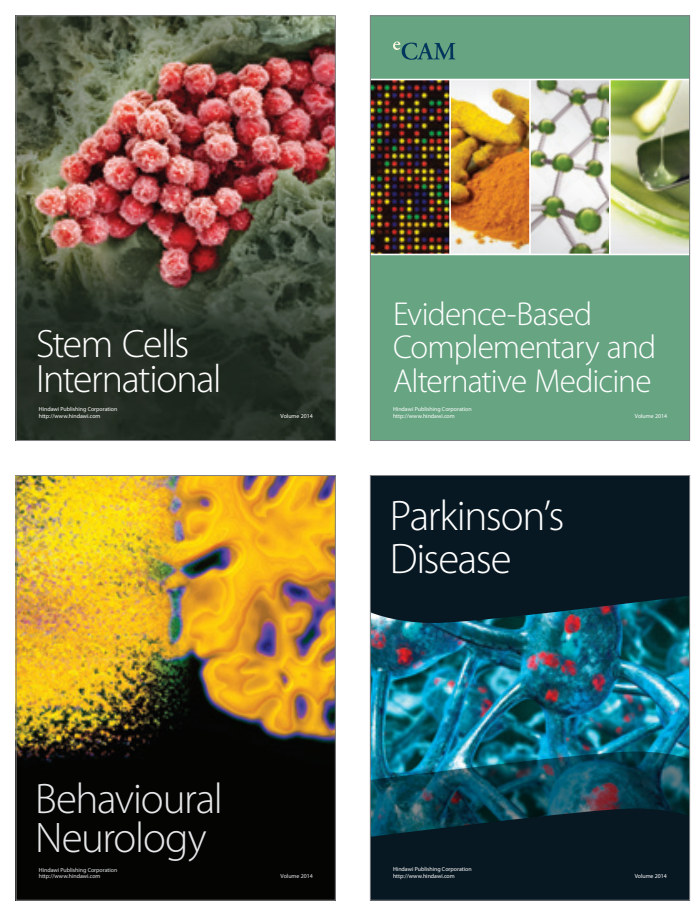

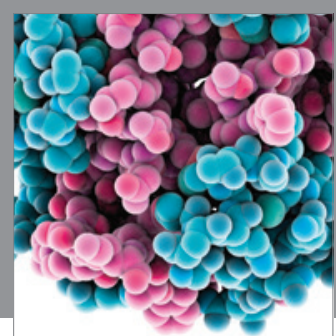

Journal of
Diabetes Research

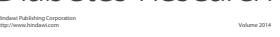

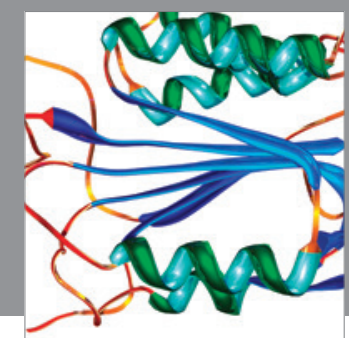

Disease Markers
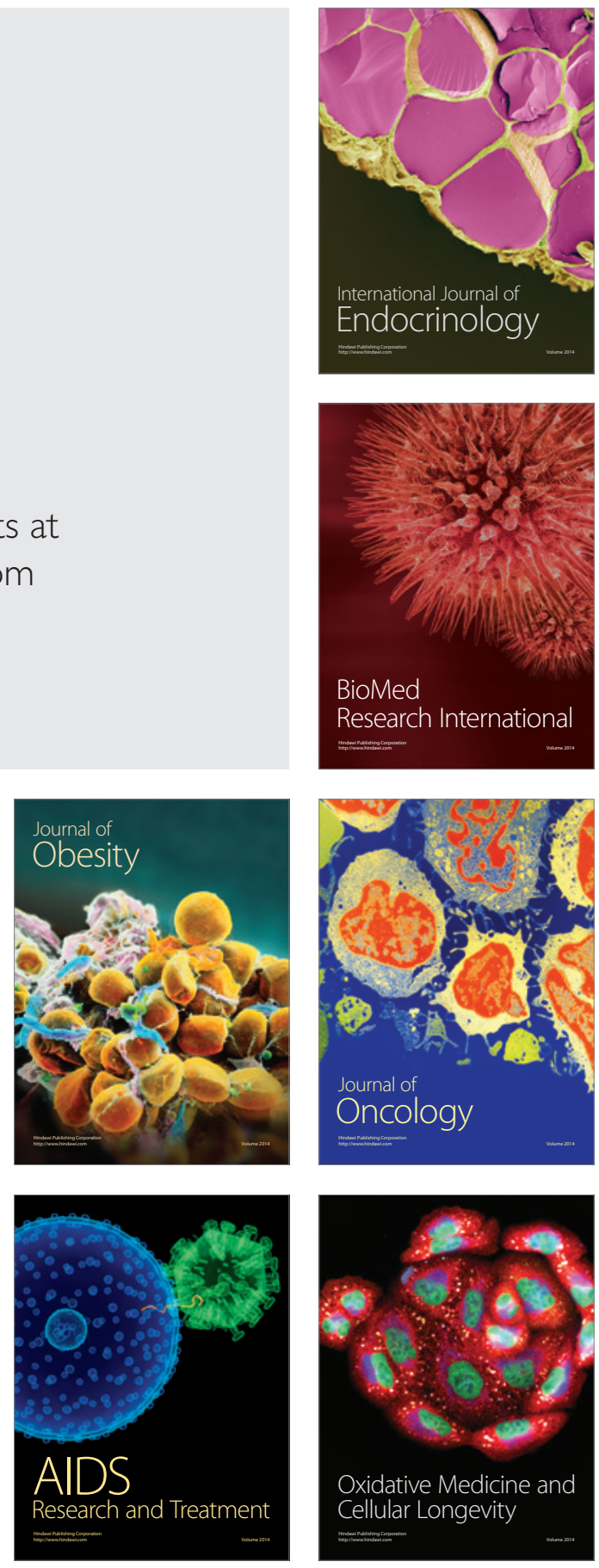